\title{
Anaerobic microbiota: spatial-temporal changes in the sediment of a tropical coastal lagoon with ephemeral inlet in the Gulf of Mexico
}

\author{
María del Rocío Torres-Alvarado ${ }^{1 *}$, Laura G. Calva-Benítez ${ }^{1}$, Sergio Álvarez-Hernández ${ }^{1}$ \& \\ Gloria Trejo-Aguilar ${ }^{2}$ \\ 1. Departamento de Hidrobiología, Universidad Autónoma Metropolitana-Iztapalapa. C. P. 09340, Ciudad de México, \\ México; rta@xanum.uam.mx, cblg@xanum.uam.mx, ahsh@xanum.uam.mx \\ 2. Departamento de Biotecnología. Universidad Autónoma Metropolitana-Iztapalapa. C. P. 09340, Ciudad de México, \\ México; gmta@xanum.uam.mx \\ * Correspondence
}

Received 14-XII-2015. Corrected 10-VII-2016. Accepted 10-VIII-2016.

\begin{abstract}
Sulfate-reducing bacteria (SRB) and methanogenic archaea (MA) share common niches in coastal sediments during the terminal phases of the anaerobic mineralization of organic matter. The purpose of this study was to analyze the spatial - temporal variation of SRB and MA in the sediments of a tropical coastal lagoon with ephemeral inlet (La Mancha, Veracruz, Gulf of Mexico) and its relationship with environmental changes. A total of 24 sediment samples were collected during the dry (April, May), rainy (July, September) and Northern (November, February) seasons in the period 2013-2014. Microbiological analyses included the quantification of the viable SRB and MA with different substrates, as well as mineralization experiments to determine the effect of sulfate on acetate oxidation. The analyzed environmental variables in the sediments included: temperature, $\mathrm{pH}$, Eh, salinity, sulfates, $\mathrm{H}_{2} \mathrm{~S}$, volatile solids, carbohydrates, and granulometric characteristics. Major changes occurred between the dry and rainy seasons. During the dry season, sulfate-reducing abundance was significantly greater with lactate $\left(8.3 \times 10^{5}-1.2 \times 10^{7}\right.$ cells $\left./ \mathrm{g}\right)$ and propionate $\left(1.8 \times 10^{5}-6.6 \times 10^{6}\right.$ cells / g) as substrates, while the MA that use methanol were dominant $\left(4.2 \times 10^{5}-9.1 \times 10^{6}\right.$ cells $\left./ \mathrm{g}\right)$. In contrast, during the rainy season, hydrogenophylic $\left(2.6 \times 10^{5}-8.3 \times 10^{6}\right.$ cells/g) and acetoclastic $\left(5.4 \times 10^{5}-6.4 \times 10^{6}\right.$ cells $\left./ \mathrm{g}\right) \mathrm{MA}$ increased significantly and SRB decreased in the analyzed substrates. An apparent competition for acetate was observed, with a greater oxidation in the media with sulfates in the dry season $(0.06 \mathrm{mM}$ acetate $/ \mathrm{g}$ sediment / day $)$, and a greater oxidation in the media without sulfates in the rainy season ( $0.02 \mathrm{mM}$ acetate / $\mathrm{g}$ sediment / day). SRB and MA were present throughout the sediment column, however SRB dominated in the first centimeters of the sediment while MA were abundant in deeper layers. In conclusion, SRB and MA together played a role in the mineralization of organic matter in the sediments of La Mancha lagoon, with sulfate-reduction dominating in the dry season (closed inlet) and methanogenesis during the rainy season (open inlet). Changes in rainfall and river input in this lagoon significantly affect salinity and sulfate content, the main factors that regulate the dynamics of SRB and MA in the sediments. Rev. Biol. Trop. 64 (4): 1759-1770. Epub 2016 December 01.
\end{abstract}

Key words: sulfate-reducing bacteria, methanogenic archaea, lagoon sediments, tropical region, seasonal changes, spatial changes, Gulf of Mexico.

Coastal lagoons represent a link between terrestrial and marine environments. They are characterized by an intense primary production, and high concentrations of organic matter in the sediment. This results in a high heterotrophic microbial activity in the surface layer of the sediment, which causes depletion in oxygen and generates anoxic and markedly reducing conditions a few millimeters below it (Böttcher et al., 2000). The absence of oxygen and the abundance of organic matter create an optimum environment for the development of diverse 
groups of anaerobic microorganisms, including sulfate-reducing bacteria (SRB) and methanogenic archaea (MA).

SRB and MA are active in the terminal phases of organic matter oxidation in marine and coastal sediments, including estuaries and coastal lagoons, where they play an important role in the carbon and sulfur cycles (Takii \& Fukui, 1991). SRB, through the process of sulfate-reduction, in environments where there is a constant input of sulfates are the main microorganisms responsible of the anaerobic mineralization of organic matter, with a capacity to degrade up to $50 \%$ (Jørgensen, 1982; Jørgensen \& Bak, 1991). Although coastal and marine environments are the most characteristic habitats of SRB, the presence of MA has also been recorded in relatively high numbers in the freshwater region of estuaries and in salt marshes, which provide an important source of substrates for MA (Franklin, William, \& Whitman, 1988; King, 1994; Takai \& Hirokoshi, 2000). MA, through methanogenesis, may play an important role in the liberation of $\mathrm{CH}_{4}$ and $\mathrm{CO}_{2}$ from coastal systems to the atmosphere (Marty, Bonin, Michotey, \& Bianci, 2001).

Diverse studies have analyzed the SRB and MA interactions in anoxic sediments, particularly in estuaries of temperate latitudes. It has been established that there is a salinity gradient from the freshwater region to the area near the sea that generates a spatial separation of the terminal processes of anaerobic mineralization: sulfate-reduction dominates in the sulfate-rich marine areas, while methanogenesis prevails in the sulfate-poor freshwater areas (Purdy, Nedwell, Embley, \& Takii, 2001; Purdy, Munson, Nedwell, \& Embley, 2002). Similarly, changes within the sediment column have been observed, with a higher abundance and activity of SRB in the first centimeters and a higher abundance of MA at greater depth where the redox potential is more negative (Böttcher et al., 2000; Wilms, Sass, Köpke, Cypionka, \& Engelen, 2007).

Regarding their nutritional capacity, it has been proven that lactate, acetate, propionate and hydrogen are the main substrates for sulfate-reduction (Fukui, Suh, Yonezawa, \& Urushigawa, 1997; Mudryk, Podgórska, Ameryk, \& Bolalek, 2000; Purdy, Munson, Creswell-Maynard, Nedwell, \& Embley, 2003), while MA obtain their energy from the conversion of a limited number of substrates: acetate, hydrogen and reduction of the methyl group from methanol and methylamines (Segers \& Kengen, 1998; Lyimo, Pol, \& Op den Camp, 2002). A niche overlap occurs between SRB and MA when using hydrogen and acetate, which may result in a competition for these substrates, with a predominance of sulfatereduction in sulfate-rich ecosystems (Taketani, Yoshiura, Dias, Andreote, \& Tsai, 2010).

Coastal lagoons, in contrast with estuaries, have a restricted communication with the sea. Also, tropical latitudes are characterized by significant fluctuations in river inputs and in the associated hydrological gradients that affect biogeochemical processes in the sediment as a result of the markedly seasonal rain patterns. Few studies have evaluated the dynamics of SRB and MA in sediments of tropical lagoons. However, from these it has been established that the MA that use methanol and methylamines are the main microbial component in the sediments of coastal lagoons that are associated with mangroves (Ramamurthy, Mohanraju, \& Natarajan, 1990; Mohanraju \& Natarajan, 1992).

Considering that there is little available information that simultaneously analyzes the dynamics of SRB and MA in tropical coastal ecosystems with a variability in river input and salinity regime, the purposes of this study were to record the abundance and distribution of the SRB and MA in the sediments of a tropical coastal system located in the Gulf of Mexico as a response to the physicochemical variations in the sediments, and to evaluate their competition for acetate.

\section{MATERIALS AND METHODS}

Study area: The coastal lagoon of La Mancha is located on the coast of the Gulf of Mexico (in the state of Veracruz) at 
$19^{\circ} 34^{\prime} \mathrm{N}-96^{\circ} 22^{\prime} \mathrm{W}$. The lagoon has a length of $3 \mathrm{~km}$, a surface area of $1400 \mathrm{~km}^{2}$, and receives freshwater discharge from Caño Grande river and by groundwater (Lara-Domínguez, Day, Yañez-Arancibia, \& Sainz-Hernández, 2006).

The climate of the region is warm and subhumid, with an average annual temperature of $24.8^{\circ} \mathrm{C}$, a mean precipitation of $1767 \mathrm{~mm}$ / year and three climatic seasons: dry (February to May), rainy (June to September) and Northern (October to February). The system is characterized by high temperature and low precipitation $(44 \pm 37 \mathrm{~mm}$ ) during the dry season. Maximum rainfall $(224 \pm 25 \mathrm{~mm})$ and an increase in river inputs and terrestrial runoff, that increase turbidity in the lagoon, are common during the rainy season. Polar winds with an average speed of $10 \mathrm{~km} / \mathrm{h}$ that cause a decrease in temperature are present during the Northern (Contreras, 1993; Ruíz-Guerrero \& López-Portillo, 2014). La Mancha lagoon has an ephemeral inlet with a seasonal communication with the sea. The inlet is open during the rainy season and generally closes at the beginning of Northern season when freshwater flow decreases, and remains closed through the dry season.

Field work: Sediment samples were collected during the three climatic seasons: dry (April and May, 2013), rainy (July and September, 2013) and Northern (November, 2013; February, 2014) at two stations in La Mancha lagoon using a Pexiglass coring device $(4.5 \mathrm{~cm}$ diameter, $40 \mathrm{~cm}$ length) with a series of $1.5 \mathrm{~cm}$ diameter holes placed in a spiral and separated by a distance of $5 \mathrm{~cm}$. Through these holes and at three depths in the sediment $(5,10$ and 15 $\mathrm{cm})$, in situ data was recorded for temperature with a thermometer (- 10 to $60{ }^{\circ} \mathrm{C}$ ), redox potential (Eh) and hydrogen ion concentration $(\mathrm{pH})$ with Instrulab electrodes. The data were recorded in an Ioanalyser (Conductronic $\mathrm{pH}$ 120). For the redox potential a platinum electrode and a saturated calomel reference electrode were used, with a reference potential of $+198 \mathrm{mV}$ added to the measured value.
The samples were then transported to the laboratory and kept at $4{ }^{\circ} \mathrm{C}$.

Laboratory analysis: The cores obtained from each locality were segmented in two layers $(0-5 \mathrm{~cm}$ and $5-10 \mathrm{~cm})$ under a nitrogen environment. Physicochemical and microbiological analyses were carried out on these layers.

For the physicochemical analysis, sediment samples were centrifuged at 1602.76 gf for 20 minutes to separate the pore water from the sediment. The pore water was filtered through $0.45 \mu \mathrm{m}$ membranes, and salinity, sulfates and total carbohydrates were evaluated. The content of total solids (TS) and volatile solids (VS) were quantified in moist sediments. The techniques used for each variable are mentioned in Torres-Alvarado, Fernández, Ramírez-Vives and Varona-Cordero (2013). Grain size distribution in the sediment was analyzed following Folk's (1969) technique.

Enumeration of viable SRB and MA was performed using the Roll Tube and Most Probable Number methods, respectively, by a tenfold dilution series $\left(10^{-1}\right.$ to $\left.10^{-10}\right)$ for each sample using four tubes per dilution. The analysis of the SRB included quantification with three substrates: lactate, acetate, and propionate using Postgate's (1963) culture medium. For the MA, quantifications with acetate, $\mathrm{CO}_{2}+\mathrm{H}_{2} \mathrm{O}$ and methanol were carried out using the medium of Balch, Fox, Magrum, Woese and Wolfe (1979). The tubes for the analysis of the SRB were incubated at $32{ }^{\circ} \mathrm{C}$ for 14 days and the black colonies were counted. The tubes for the analysis of the MA were incubated at $32{ }^{\circ} \mathrm{C}$ for one month and those that presented methane production were evaluated as positive. Methane was detected according TorresAlvarado et al. (2003).

The effect of sulfate on acetate oxidation was evaluated through mineralization experiments in which sediment samples were inoculated in serum bottles with Balch et al. (1979) culture medium and acetate as substrate, at a final concentration of $20 \mathrm{mM}$. The experiments were carried out both in the presence and absence of sulfates $(20 \mathrm{mM})$ and 
with the corresponding controls (without substrate). Acetate concentration was measured during 30 days, three times per week, with a Agilent Serie 6890 Plus gas chromatograph with a flame ionization detector (FID) and a 15 $\mathrm{m} \times 0.530 \mathrm{~mm} \times 1.00 \mu \mathrm{m}$ Agilent crosslinked FFAP capillary column. Temperatures were $130{ }^{\circ} \mathrm{C}$ in the injector, $120{ }^{\circ} \mathrm{C}$ in the column and $150{ }^{\circ} \mathrm{C}$ in the detector. The carrier gas was $\mathrm{N}_{2}(4.5 \mathrm{ml} / \mathrm{min})$. Acetate was identified from a standard solution with a mixture of acetate, propionate and butyrate $10 \mathrm{mM}$.

Statistical analysis: The data matrix included SRB and MA abundances, and physicochemical variables. For the temporal analysis variables were grouped into three seasons (dry, rainy and Northern); for the spatial analysis, data were grouped into two categories (0 - $5 \mathrm{~cm}$ and $5-10 \mathrm{~cm}$ ). An analysis of variance (ANOVA) was conducted to test for significant differences between seasons, and between depth categories. A principal components analysis (PCA) was applied to reduce the dimension of the data and extract the most important variables. The eigenvalues considered for PCA were $>0.50$ and $<-0.50$. A canonical correspondence analysis (CCA) was used to determine the relationship between the microbial abundance and the environmental variables (Ter Braak, 1986).

\section{RESULTS}

Physicochemical characteristics in the sediment: Data for the physicochemical variables in the sediment and porewater of the $\mathrm{La}$ Mancha lagoon are presented in table 1.

Temperature showed a significant temporal variability (Anova $=67.20, \mathrm{P}=0.000000$ ), with the highest average value during the dry season and the lowest during the Northern. $\mathrm{pH}$ values changed significantly with the seasons (Anova $=33.61, P=0.000000)$, with alkaline conditions during the dry months and neutral and slightly acid conditions during the Northern and rainy seasons. The Eh was more reducing during the dry season, however significant temporal changes were not recorded. Salinity $($ Anova $=235.93, \mathrm{P}=0.00)$, sulfate (Anova $=23.25, \mathrm{P}=0.000005)$, and $\mathrm{H}_{2} \mathrm{~S}$ (Anova $=$ $14, \mathrm{P}=0.000137$ ) increased during the dry season and decreased during the rains. The inorganic fraction of the sediments did not present significant temporal or spatial changes; however, volatile solids (Anova $=6.59, \mathrm{P}=$ 0.006319 ) and carbohydrates (Anova $=3.66$, $\mathrm{P}=0.043308$ ) increased during the rainy

TABLE 1

Environmental parameters in sediments of La Mancha coastal lagoon

\begin{tabular}{lcccccc}
\multicolumn{1}{c}{ Parameter } & $\begin{array}{c}\text { Dry } \\
0-5 \mathrm{~cm}\end{array}$ & $\begin{array}{c}\text { Dry } \\
5-10 \mathrm{~cm}\end{array}$ & $\begin{array}{c}\text { Rainy } \\
0-5 \mathrm{~cm}\end{array}$ & $\begin{array}{c}\text { Rainy } \\
5-10 \mathrm{~cm}\end{array}$ & $\begin{array}{c}\text { Northern } \\
0-5 \mathrm{~cm}\end{array}$ & $\begin{array}{c}\text { Northern } \\
5-10 \mathrm{~cm}\end{array}$ \\
Temperature $\left({ }^{\circ} \mathrm{C}\right)$ & $31.8 \pm 0.2$ & $30.5 \pm 0.6$ & $29.3 \pm 0.7$ & $28.8 \pm 0.3$ & $24 \pm 2$ & $23.5 \pm 2$ \\
$\mathrm{pH}$ & $7.9 \pm 0.2$ & $7.9 \pm 0.2$ & $6.8 \pm 0.2$ & $6.9 \pm 0.3$ & $7.1 \pm 0.1$ & $7.5 \pm 0.2$ \\
Eh $(\mathrm{mV})$ & $-23.5 \pm 69$ & $-122.5 \pm 10$ & $70 \pm 42$ & $-82.5 \pm 27$ & $39 \pm 1$ & $-147.5 \pm 5$ \\
Salinity $(\mathrm{psu})$ & $28.2 \pm 1.5$ & $28.6 \pm 2.2$ & $1.4 \pm 1.6$ & $0.9 \pm 0.9$ & $10.9 \pm 3.8$ & $13 \pm 4.1$ \\
Sulfates $(\mathrm{mM})$ & $10.2 \pm 0.8$ & $6.5 \pm 1.7$ & $1.5 \pm 1.6$ & $0.7 \pm 1.3$ & $6.1 \pm 2.6$ & $4 \pm 1.9$ \\
$\mathrm{H}_{2} \mathrm{~S}(\mathrm{mM})$ & $2.3 \pm 1.2$ & $1.6 \pm 0.8$ & $0.2 \pm 0.0$ & $0.1 \pm 0$ & $1.9 \pm 0.1$ & $1.2 \pm 0.8$ \\
Carbohydrates $(\mathrm{mg} / \mathrm{L})$ & $2.9 \pm 0.6$ & $1.8 \pm 0.6$ & $5.5 \pm 0.8$ & $3.1 \pm 2.4$ & $3.3 \pm 1.4$ & $1.7 \pm 1.4$ \\
Inorganic solids $(\mathrm{g} / \mathrm{L})$ & $319.1 \pm 91$ & $363.8 \pm 57$ & $420.3 \pm 234$ & $416.8 \pm 25$ & $363.7 \pm 135$ & $435.7 \pm 150$ \\
Organic solids $(\mathrm{g} / \mathrm{L})$ & $9.7 \pm 5.2$ & $12.6 \pm 3.6$ & $24.3 \pm 13.0$ & $27.5 \pm 14.5$ & $21.5 \pm 1.2$ & $20.7 \pm 0.3$ \\
Sand $(\%)$ & $85 \pm 2.8$ & $85.2 \pm 4.6$ & $93.1 \pm 2.7$ & $90.1 \pm 1.8$ & $89.2 \pm 0.7$ & $89.4 \pm 0.8$ \\
Mud $(\%)$ & $9.9 \pm 2.9$ & $8.4 \pm 2.8$ & $2.9 \pm 1.7$ & $4.3 \pm 1.5$ & $5.4 \pm 1.1$ & $5.4 \pm 1.1$ \\
Clay $(\%)$ & $5 \pm 0.1$ & $6.4 \pm 2.8$ & $3.8 \pm 1.3$ & $5.5 \pm 0.9$ & $5.3 \pm 1.1$ & $5.1 \pm 1.2$ \\
\hline
\end{tabular}

Mean \pm Standard deviation. 
season in comparison with the Northern and dry seasons. The sand fraction was significantly greater during the rains (Anova $=13.02$, $\mathrm{P}=0.000210)$, while the silt fraction was greater during the dry season (Anova $=16.43$, $\mathrm{P}=0.000051$ ).

The physical and chemical characteristics of the sediment changed with depth in the sediment column. Eh (Anova $=58.07, \mathrm{P}=$ 0.000000 ), salinity (Anova $=1.10, \mathrm{P}=0.03$ ), sulfate concentration $($ Anova $=2.34, \mathrm{P}=0.04)$ and carbohydrates (Anova $=6.78, \mathrm{P}=0.000$ ) decreased significantly with depth, whereas the other parameters did not vary significantly.

\section{Methanogen and sulfate-reducing abun-} dance: Significant temporal variations in the abundance of the viable SRB and MA were recorded in the sediment. The greatest densities of SRB were quantified at closed inlet conditions, mainly during the dry season for the physiological groups that use lactate $\left(8.3 \times 10^{5}\right.$ $-1.2 \times 10^{7}$ cells / g) and propionate $\left(1.8 \times 10^{5}\right.$ $6.6 \times 10^{6}$ cells $/ \mathrm{g}$ ), the difference was statistically significant in the case of the SRB that use lactate (Anova $=11.85, \mathrm{P}=0.000359)$; at the contrary the group that utilized acetate was significantly more abundant during the Northern $\left(4.7 \times 10^{4}-4.5 \times 10^{6}\right.$ cells $/ \mathrm{g}$ sediment $)($ Anova $=$ $4.52, \mathrm{P}=0.023241$ ) (Fig. 1). In the case of MA the group that grows on methanol recorded a maximum density during the dry season with $4.2 \times 10^{5}-9.1 \times 10^{6}$ cells $/ \mathrm{g}($ Anova $=7.78, \mathrm{P}=$ $0.002964)$, while the abundance of the MA that use acetate $\left(2.5 \times 10^{1}-7.5 \times 10^{4}\right.$ cells $/ g$ sediment $)$ and hydrogen $\left(4.3 \times 10^{2}-3.7 \times 10^{6}\right.$ cells / g sediment) decreased (Fig. 1).

During the rainy season, when the inlet was open, the abundance of the sulfatereducing populations with the three analyzed substrates decreased, the data recorded were $1.5 \times 10^{3}-2.2 \times 10^{5}, 1.0 \times 10^{3}-7.1 \times 10^{4}$ and $1.8 \times 10^{3}$ - $5.5 \times 10^{4}$ cells / g with lactate, propionate and acetate, respectively. At the contrary MA that used acetate and hydrogen were more abundant with $5.4 \times 10^{5}-6.4 \times 10^{6}$ and $2.6 \times 10^{5}$ - $8.3 \times 10^{6}$ cells / g sediment, respectively; however, the differences were significant only for the acetoclastic MA (Anova $=9.19$, $\mathrm{P}=0.001357$ ) (Fig. 1).

The density of the SRB presented a spatial variation with the highest values in the upper five centimeters of the sediment, though the difference was significant only with lactate (Anova $=5.17, \mathrm{P}=0.033082)$. There were significant changes in the case of the MA, but in contrast with the SRB, the maximum abundance was recorded in the $5-10 \mathrm{~cm}$ layer for the acetoclastic MA (Anova $=6.07, \mathrm{P}=$ 0.022073 ), the hydrogenophylic MA (Anova $=7.61, \mathrm{P}=0.011448)$, and the physiological group that uses methanol (Anova $=4.57$, $\mathrm{P}=0.043820)$.

Acetoclastic activity: Acetate, together with other volatile fatty acids (propionate, butyrate) increased during the first days of incubation and decreased from the fifth day until to a minimum at the end of the experiment. Acetate oxidation was greater in the media with sulfates in the samples of the dry season (0.06 mM acetate / g sediment / day), and increased in the media without sulfates of the rainy season $(0.02 \mathrm{mM}$ acetate / $\mathrm{g}$ sediment / day). Acetate concentration remained low in the control sediments, with values of only $5 \%$ of those recorded for the enriched sediments.

Environmental variables and anaerobic microbiota: The PCA indicated that the first component explained $41.40 \%$ of the total variance and the second explained $15.01 \%$. The ordination diagram of components 1 and 2 presented a seasonal pattern (Fig. 2A). For component 1 , the sites located in the upper left panel corresponded to the dry season and were characterized by a greater salinity, sulfate and $\mathrm{H}_{2} \mathrm{~S}$ concentration, and silt. The sites located on the opposite side corresponded to the rainy season and were characterized by a dominance of sand, neutral and slightly acid $\mathrm{pH}$ values, less reducing Eh values, and a greater concentration of volatile solids. The Northern season represented an intermediate season between the dry and rainy seasons. 


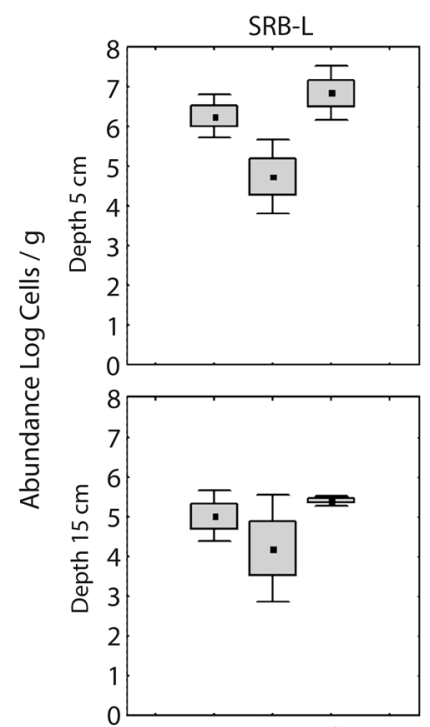

Dry Rainy Northern

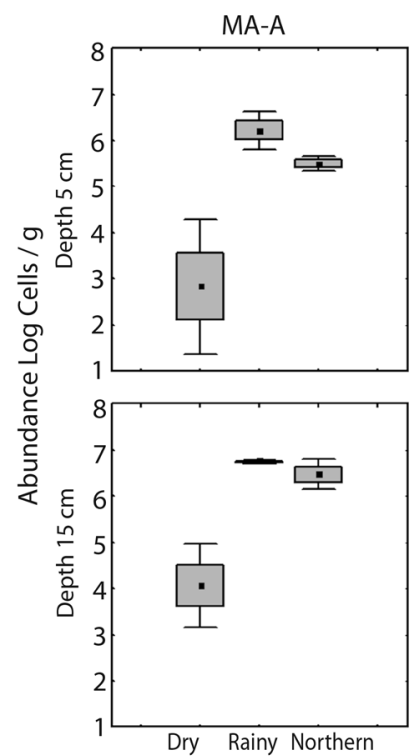

SRB-P
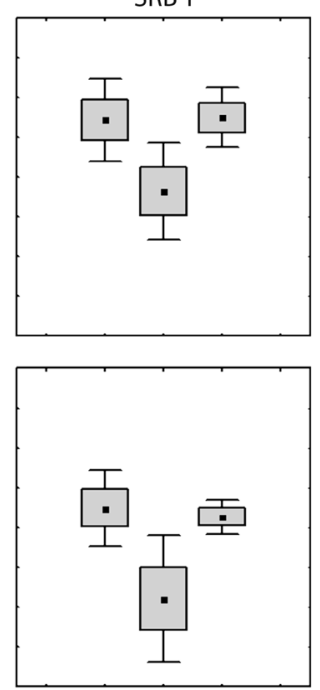

Dry Rainy Northern

Season

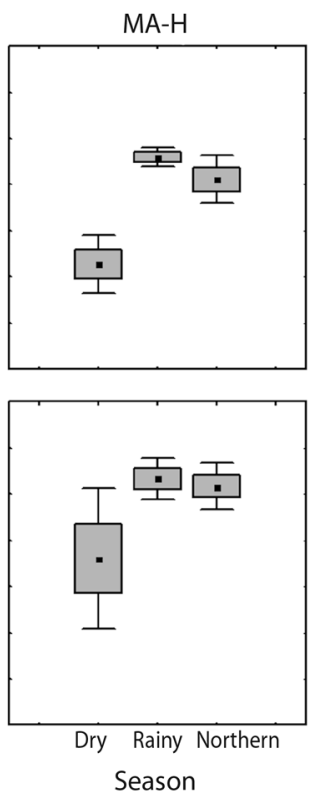

SRB-A
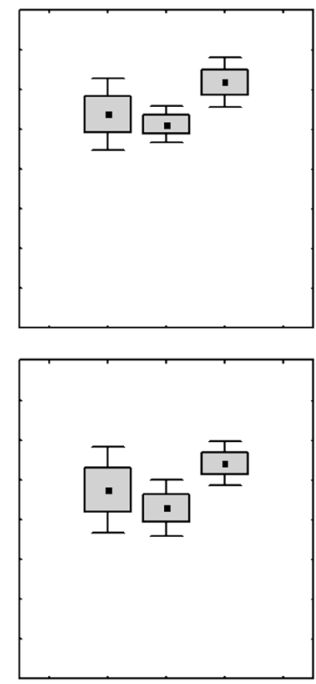

Dry Rainy Northern
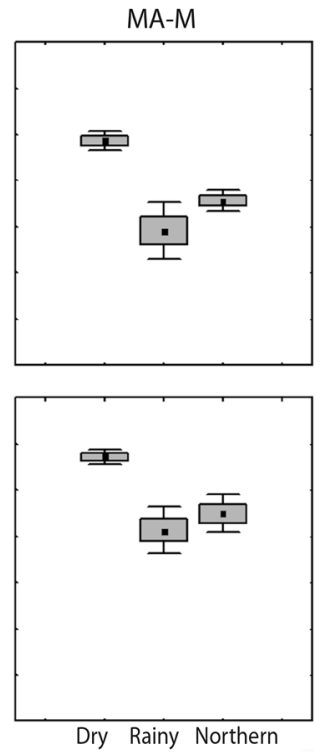

Fig. 1. A. Spatial-temporal variation of SRB in the sediments of the coastal lagoon of La Mancha, Veracruz. Fig. 1. B. Spatial-temporal variation of MA in the sediments of the coastal lagoon of La Mancha, Veracruz.

The correlation coefficients between the environmental variables and the ordination axes obtained with the PCA showed the relative importance of each environmental variable in the distribution and composition of the microbial community. The microbiota-environment correlation was 0.96 for axis 1 , and 0.83 for axis 2 . The ordination diagram showed a change in the structure of the SRB and MA (Fig. 2B). Axis 1 corresponded to the sites with greater salinity, sulfate concentration and temperature, where the SRB component became associated 

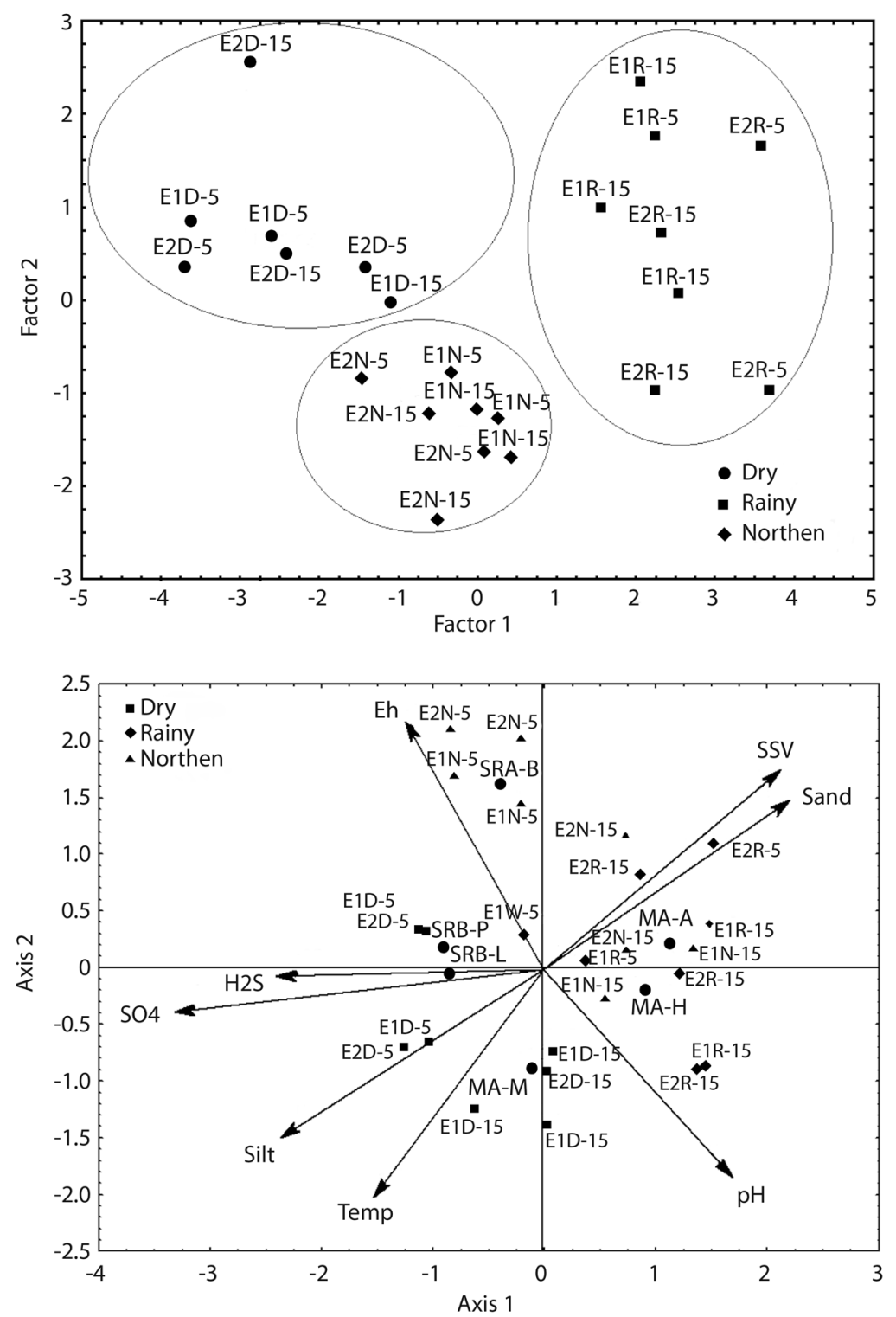

Fig. 2. A. PCA ordination. E1D-5. sample station 1, Dry-0-5 cm; E1-D15. sample station 1, Dry-5 to $10 \mathrm{~cm}$; E2D-5. sample station 2, Dry-0-5 cm; E2-D15. sample station 2, Dry-5 to $10 \mathrm{~cm}$; E1R-5. sample station 1, Rainy-0-5 cm; E1-R15. sample station 1, Rainy-5 to $10 \mathrm{~cm}$; E2R-5. sample station 2, Rainy-0-5 cm; E2-R15. sample station 2, Rainy-5 to $10 \mathrm{~cm}$; E1N-5. sample station 1, Northern-0-5 cm; E1-N15. sample station 1, Northern -5 to $10 \mathrm{~cm}$; E2N-5. sample station 2, Northern -0-5 cm; E2-N15. sample station 2, Northern -5 to $10 \mathrm{~cm}$

Fig. 2. B. Microbiota-environmental variable relationships. E1D-5. sample station 1, Dry-0-5 cm; E1-D15. sample station 1, Dry-5 to $10 \mathrm{~cm}$; E2D-5. sample station 2, Dry-0-5 cm; E2-D15. sample station 2, Dry-5 to $10 \mathrm{~cm}$; E1R-5. sample station 1, Rainy-0-5 cm; E1-R15. sample station 1, Rainy-5 to $10 \mathrm{~cm}$; E2R-5. sample station 2, Rainy-0-5 cm; E2-R15. sample station 2, Rainy-5 to $10 \mathrm{~cm}$; E1N-5. sample station 1, Northern-0-5 cm; E1-N15. sample station 1, Northern -5 to $10 \mathrm{~cm}$; E2N-5. sample station 2, Northern $-0-5 \mathrm{~cm}$; E2-N15. sample station 2, Northern -5 to $10 \mathrm{~cm}$. 
in the lower left panel of the diagram. Axis 2 was determined mainly by the volatile solids, $\mathrm{pH}$ and the percentage of sand, with the associated MA group at the right side of the diagram.

\section{DISCUSSION}

The physicochemical characteristics of the sediment in the coastal lagoon of La Mancha varied throughout the different climatic seasons, particularly salinity and sulfate content, because of changes recorded in the rainfall and the volume of the freshwater input provided by the rivers and groundwater. It has been previously established that seasonal pulses in the input of freshwater have a marked effect on the hydrodynamics and ecology of coastal lagoons (Knoppers \& Kjerfve, 1997). The changes recorded in the sedimentary habitat influenced the distribution and abundance of the SRB and MA temporally.

Salinity and sulfates increased during the dry season, as result of a minor freshwater inflow and an increase of the evaporation rate (Lara-Domínguez et al. 2006). The sediment presented alkaline conditions and a greater percentage of silt with a low hydraulic conductivity that favored the presence of more reducing characteristics (Böttcher et al., 2000). The SRB that dominated under these conditions were those of the physiological groups that use lactate and propionate, which are produced during fermenting microbial activity. Lactate may be used as an electron donor by most SRB species, except for Desulfobacter and some species of the genus Desulfobacterium (Castro, Reddy, \& Ogram, 2002). Sediments rich in organic matter cause a rapid development, mainly of the species of the genus Desulfovibrio (Parkes, Gibson, Mueller-Harvey, Buckingham, \& Herebert, 1989; Widdel \& Hansen, 1992). Propionate is the substrate used in estuarine and salt marsh sediments by species of the genus Desulfobulbus, and it seems that the presence of sulfates is a requisite for its consumption (Visser, Beeksman, van der Zee, Stams, \& Lettinga, 1993; Boschker, de Graaf, Köster, Meyer-Reil, \& Cappenberg, 2001).
This may explain the increase in the SRB that use propionate in the dry season, when the content of sulfates was greater. The greater density and activity of the SRB during the dry season could have been responsible for the levels of $\mathrm{H}_{2} \mathrm{~S}$ quantified during this season. A positive relationship between the abundance and concentration of sulfide has been reported for estuarine sediments.

During the dry season MA that use methanol were dominant. In environments with an abundance of sulfates it is possible to detect the production of methane due some MA may use non-competitive substrates that are not accessible to SRB. Simple substrates such as methanol, mono-, bi- and trimethylamine are important to methanogens, while SRB are capable of degrading more complex substances (Lyimo et al., 2002; Wilms et al., 2007; Muyzer \& Stams, 2008). Methanol is liberated after the decomposition of lignin or pectin, present in the cell wall of mangrove trees, and may be used by species of the genus Methanococcus (Purdy et al., 2002, 2003).

The increase in freshwater input during the rainy season decreased salinity and sulfate content, and resuspended the sediments. The percentage of sand increased generating less reducing conditions. The increase in VS and carbohydrates during this season may be related to the input of organic matter provided by runoff from adjacent land and wetlands (Preston \& Prodduturu, 1992). The hydrogenophylic and acetoclastic MA increased during the rainy season. Their presence is related to the low availability of sulfates and to the relatively high inputs of organic matter that may have offered a favorable niche for their development (Fitzsimons, Dawit, Revitt, \& Rocha, 2005). Methanogens may increase in number when low levels of sulfates are present in coastal areas, as they are capable of using $\mathrm{H}_{2}$ and acetate (Fukui et al., 1997). It has been established that $30-40 \%$ of the methane generated in sediments is formed from hydrogen that is used by Methanobacterium and Methanobrevibacter (Conrad, 1999), whereas acetate generates approximately two thirds of the methane 
that may be used by the genera Methanosarcina and Methanococcoides. Increases in MA during the rainy season have been reported for other tropical lagoon systems (Preston \& Prodduturu, 1992; Torres et al., 2013).

The mineralization experiments indicated that sulfate-reduction apparently dominated the acetate oxidation when sulfates were available in the medium, as a result of the SRB having a higher affinity (low $K_{\mathrm{m}}$ ) for acetate in comparison with the MA, with $K_{\mathrm{m}}$ values of $200 \mu \mathrm{M}$ and $3 \mathrm{mM}$ for the SRB and the MA, respectively (Schönheit, Kristjanson, \& Thauer, 1982). Mountfort, Asher, Mays and Tiedje (1980) suggested that the function of the SRB depends on the existing levels of sulfates, because they oxidize acetate at high concentrations, whereas producing acetate at low levels of sulfates releasing substrate for methanogens. The experiments of Banat and Nedwell (1983) with inhibitors of sulfate-reduction showed that the SRB are the main microorganisms responsible for the oxidation of acetate to $\mathrm{CO}_{2}$ in salt marsh sediments, while the proportion of acetate that was metabolized to methane was negligible. Although there is an apparent competition for acetate between the sulfate reducing and the methanogen populations, the growth of both groups with the different analyzed substrates may indicate the existence of a nutritional flexibility in which the generalists use a variety of carbon sources rather than competing for a common substrate. The cometabolism of a wide range of substrates may present a competitive advantage, especially under nutrient-limiting conditions (Egli, 1995).

On the spatial scale, the SRB were preferentially distributed in the first five centimeters of the sediment column where the availability of sulfates and labile organic matter (carbohydrates) was higher. In contrast with the SRB, the MA were abundant at greater depths where sulfate concentration was lower and redox potential was more negative. This agrees with other reports on sediments of estuaries and mangroves (Zepp-Falz et al., 1999; Böttcher et al., 2000; Lyimo et al., 2002). Despite the observed distribution pattern, the presence of SRB and MA throughout the sedimentary profile proved the co-existence of these two functional groups of microorganisms, as has been described in other studies, as the result of the constant input of organic matter to the system that decreases competition for substrates, and of the capacity of the anaerobic microbiota to use non-competitive substrates such as methanol (Holmer \& Kristensen, 1994; Wilms et al., 2007; Taketani et al., 2010).

In conclusion, SRB and MA together played a role in the mineralization of organic matter in the sediments of La Mancha lagoon, with sulfate-reduction dominating in the dry season (closed inlet) and methanogenesis during the rainy season (open inlet). Sulfate-reducing and methanogen populations can co-exist due to the constant input of organic matter, which allows the use of non-competitive substrates. Changes in rainfall and river input in this lagoon significantly affect salinity and sulfate content, the main factors that regulate the dynamics of SRB and MA in these sediments.

\section{ACKNOWLEDGMENTS}

The authors thank to the Universidad Autónoma Metropolitana-Iztapalapa for funding this study through the project "Caracterización de los Ecosistemas Costeros Mexicanos".

\section{RESUMEN}

Microbiota anaerobia: cambios espacio-temporales en el sedimento de una laguna costera tropical con boca efímera en el Golfo de México. Las bacterias sulfatorreductoras (BSR) y las arqueas metanogénicas (AM) comparten nichos comunes en los sedimentos costeros durante las fases terminales de la mineralización anaerobia de la materia orgánica. El objetivo del presente estudio fue analizar la variación espacio-temporal de las BSR y AM en los sedimentos de una laguna costera tropical con una boca efímera (La Mancha, Veracruz, Golfo de México) y su relación con los cambios ambientales. Un total de 24 muestras de sedimentos fueron recolectadas en las temporadas de secas (abril, mayo), lluvias (julio, septiembre) y nortes (noviembre, febrero) en el periodo 2013 - 2014. Los análisis microbiológicos incluyeron la cuantificación de las BSR y AM viables con diferentes sustratos, así como experimentos de mineralización para determinar el efecto 
de los sulfatos en la oxidación del acetato. Las variables ambientales analizadas en los sedimentos incluyeron la temperatura, $\mathrm{pH}$, Eh, salinidad, sulfatos, $\mathrm{H}_{2} \mathrm{~S}$, sólidos volátiles, carbohidratos y las características granulométricas. Los principales cambios se presentaron entre las estaciones de secas y lluvias. En la temporada de secas la abundancia sulfatorreductora fue significativamente superior con lactato $\left(8.3 \times 10^{5}-1.2 \times 10^{7}\right.$ células $\left./ \mathrm{g}\right) \mathrm{y}$ propionato $\left(1.8 \times 10^{5}\right.$ - $6.6 \times 10^{6}$ células / g) como sustratos, mientras que las AM que emplean metanol dominaron $\left(4.2 \times 10^{5}-9.1 \times 10^{6}\right.$ células $/ \mathrm{g}$ ). Por el contrario, en la época de lluvias aumentaron significativamente las AM hidrogenofílicas $\left(2.6 \times 10^{5}-8.3 \times 10^{6}\right.$ células / g) y acetoclásticas $\left(5.4 \times 10^{5}-6.4 \times 10^{6}\right.$ células / g), disminuyendo las BSR con los sustratos analizados. Se determinó una competencia aparente por el acetato. Su oxidación fue mayor en los medios con presencia de sulfatos en las temporadas de secas $(0.06 \mathrm{mM}$ acetato / $\mathrm{g}$ sedimento / día), mientras que aumentó en los medios sin sulfatos en la época de lluvias ( $0.02 \mathrm{mM}$ acetato / g sedimento / día). Las BSR y las AM estuvieron presentes a lo largo de la columna sedimentaria; sin embargo, las BSR dominaron en los primeros centímetros del sedimento y las AM abundaron a mayor profundidad. En conclusión las BSR y AM participaron de manera conjunta en la mineralización de la materia orgánica en los sedimentos de la laguna de La Mancha, dominando la sulfatorreducción en la temporada de secas (boca cerrada) y la metanogénesis en la época de lluvias (boca abierta). Los cambios en el aporte fluvial y la precipitación en esta laguna afectaron significativamente la salinidad y el contenido de sulfatos, siendo los principales factores que regularon la dinámica de las BSR y AM en los sedimentos.

Palabras clave: bacterias sulfatorreductoras, arqueas metanogénicas, sedimentos lagunares, zona tropical, cambios estacionales, cambios espaciales, Golfo de México.

\section{REFERENCES}

Balch, W. E., Fox, G. E., Magrum, L. J., Woese, C. R., \& Wolfe, R. S. (1979). Methanogens: reevaluation of a unique biological group. Microbiological Reviews, 43, 260-296.

Banat, I. M., \& Nedwell, D. B. (1983). Mechanisms of turnover of $\mathrm{C} 2-\mathrm{C} 4$ fatty acids in high-sulphate and low-sulphate anaerobic sediments. FEMS Microbiology Letters, 17, 107-110.

Boschker, H. T. S., de Graaf, W., Köster, M., Meyer-Reil, L. A., \& Cappenberg, T. E. (2001). Bacterial populations and processes involved in acetate and propionate consumption in anoxic brackish sediment. FEMS Microbiology Ecology, 35, 97-103.

Böttcher, M. E., Hespenheide, B., Llobet-Brossa, E., Beardsley, C., Larsen, O., Schramm, A., ... Amann, R. (2000). The biogeochemistry, stable isotope geochemistry, and microbial community structure of a temperate intertidal mudflat: an integrated study. Continental Shelf Research, 20, 1749-1769.

Castro, H., Reddy, K. R., \& Ogram, A. (2002). Composition and function of sulfate-reducing prokaryotes in eutrophic and pristine areas of the Florida Everglades. Applied and Environmental Microbiology, 68, 6129-6137.

Conrad, R. (1999). Contribution of hydrogen to methane production and control of hydrogen concentrations in methanogenic soils and sediments. FEMS Microbioloy Ecology, 28, 193-202.

Contreras, E. F. (1993). Ecosistemas Costeros Mexicanos. Ciudad de México: CONABIO-UAMI.

Egli, T. (1995). The ecological and physiological significance of the growth of heterotrophic microorganisms with mixtures of substrates. In J. Gwynfryn (Ed.), Advances in Microbial Ecology (14, pp. 305-386). New York: Plenum Press.

Fitzsimons, M. F., Dawit, M., Revitt, D. M., \& Rocha, C. (2005). Effects of early tidal inundation on the cycling of methylamines in intertidal sediments. Marine Ecology Progress Series, 294, 51-61.

Folk, R. L. (1969). Petrología de Rocas Sedimentarias. México: UNAM.

Franklin, M. J., William, J. W., \& Whitman W. B. (1988). Populations of methanogenic bacteria in a Georgia salt marsh. Applied and Environmental Microbiology, $54,1151-1157$

Fukui, M., Suh, J., Yonezawa, Y., \& Urushigawa, Y. (1997). Major substrates for microbial sulfate reduction in the sediments of Ise Bay, Japan. Ecological Research, 12, 201-209.

Holmer, M., \& Kristensen, E. (1994). Coexistence of sulfate reduction and methane production in an organicrich sediment. Marine Ecology Progress Series, 107, 177-184.

Jørgensen, B. B. (1982). Mineralization of organic matter in the sea-bed, the role of sulphate reduction. Nature, 296, 643-645.

Jørgensen, B. B., \& Bak, F. (1991). Pathways and microbiology of thiosulfate transformations and sulfate reduction in a marine sediment (Kattegat, Denmark). Applied and Environmental Microbiology, 57, 847-856.

King, G. M. (1994). Associations of methanotrophs with the roots and rhizomes of aquatic vegetation. Applied and Environmental Microbiology, 60, 3220-3227.

Knoppers, B., \& Kjerfve, B. (1997). Coastal lagoons of southeastern Brazil: physical and biogeochemical characteristics. In G. M. E., Perillo, M. C. Piccolo, \& 
M. Pino-Quivira (Eds.), Estuaries of South America (pp. 35-66). Berlin, Germany: Springer.

Lara-Domínguez, A. L., Day, J. W., Yañez-Arancibia, A., \& Sainz-Hernández, E. (2006). A dynamic characterization of water flux through a tropical ephemeral inlet, La Mancha lagoon, Gulf of Mexico. In V. P. Singh \& Y. Jun (Eds.), Coastal Hydrology and Processes. Proceeding of the AIH $25^{\text {Th }}$ Anniversary Meeting and International Conference "Challenges in Coastal Hydrology and Water Quality” (pp. 413-422). Colorado, USA: Water Resources Publications.

Lyimo, T. J., Pol, A., \& Op den Camp, H. J. M. (2002). Sulfate reduction and methanogenesis in sediments of Mtoni mangrove forest, Tanzania. AMBIO. A Journal of the Human Environment, 31, 614-616.

Marty, D., Bonin, P., Michotey, V., \& Bianchi, M. (2001). Bacterial biogas in coastal systems affected by freshwater inputs. Continental Shelf Research, 21, 2105-2115.

Mohanraju, R., \& Natarajan, R. (1992). Methanogenic bacteria in mangrove sediments. Hydrobiologia, 247, 187-193.

Mountfort, D. O., Asher, R. A., Mays, E. L., \& Tiedje, J. M. (1980). Carbon and electron flow in mud and sand flat intertidal sediments at Delaware Inlet, Nelson, New Zealand. Applied and Environmental Microbiology, 39, 686-694.

Mudryk, Z. J., Podgórska, B., Ameryk, A. \& Bolalek, J. (2000). The occurrence and activity of sulphatereducing bacteria in the bottom sediments of the Gulf of Gdańsk. Oceanologia, 42, 105-117.

Muyzer, G., \& Stams, A. J. M. (2008). The ecology and biotechnology of sulphate-reducing bacteria. Nature Reviews Microbiology, 6, 441-454.

Parkes, R. J., Gibson, G. R., Mueller-Harvey, I., Buckingham, W. J., \& Herebert, R. A. (1989). Determination of the substrates for sulphate-reducing bacteria within marine and estuarine sediments with different rates of sulphate reduction. Journal of General Microbiology, 135, 175-187.

Postgate, J. R. (1963). Versatile medium for the enumeration of sulfate-reducing bacteria. Applied Microbio$\log y, 11,265-267$.

Preston, M. R., \& Prodduturu, P. (1992). Tidal variations of particulate carbohydrates in the Mersey Estuary. Estuarine and Coastal Shelf Science, 34, 37-48.

Purdy, K. J., Nedwell, D. B., Embley, T. M., \& Takii, S. (2001). Use of 16S rRNA-targeted oligonucleotide probes to investigate the distribution of sulphatereducing bacteria in estuarine sediments. FEMS Microbiology Ecology, 36, 165-168.
Purdy, K. J., Munson, M. A., Nedwell, D. B., \& Embley, T. M. (2002). Comparison of the molecular diversity of the methanogenic community at the brackish and marine sediments of a UK estuary. FEMS Microbiology Ecology, 39, 17-21.

Purdy, K. J., Munson, M. A., Creswell-Maynard, T., Nedwell, D. B., \& Embley, T. M. (2003). Use of $16 \mathrm{~S}$ rRNA-targeted oligonucleotide probes to investigate function and phylogeny of sulphate-reducing bacteria and methanogenic archaea in a UK estuary. FEMS Microbiology Ecology, 44, 361-371.

Ramamurthy, T., Mohanraju, R., \& Natarajan, R. (1990). Distribution and ecology of methanogenic bacteria in mangrove sediments of Pichavaram, east coast of India. Indian Journal of Marine Science, 19, 269-273.

Ruíz-Guerrero, M., \& López-Portillo, J. (2014). Variación espacio-temporal de la comunidad de macroinvertebrados epibiontes en las raíces del mangle rojo Rhizophora mangle (Rhizophoraceae) en la laguna costera de la Mancha, Veracruz, México. Revista de Biología Tropical, 62, 1309-1330.

Schönheit, P., Kristjansson, J. K., \& Thauer, R. K. (1982). Kinetic mechanism for the ability of sulfate reducers to out-compete methanogens for acetate. Archives of Microbiology, 132, 285-288.

Segers, R., \& Kengen, S. W. M. (1998). Methane production as a function of anaerobic carbon mineralization: a process model. Soil Biology and Biochemistry, $30,1107-1117$.

Takai, K., \& Horikoshi, K. (2000). Rapid detection and quantification of members of the archaeal community by quantitative PCR using fluorogenic probes. Applied and Environmental Microbiology, $66,5066-5072$.

Taketani, R. G., Yoshiura, C. A., Dias, A. C. F., Andreote, F. D., \& Tsai, S. M. (2010). Diversity and identification of methanogenic archaea and sulphate-reducing bacteria in sediments from a pristine tropical mangrove. Antonie van Leeuwenhoek, 97, 401-411.

Takii, S., \& Fukui, M. (1991). Relative importance of methanogenesis, sulfate reduction and denitrification in sediments of the lower Tama river. Bulletin of the Japanese Society of Microbial Ecology, 6, 1-8.

Ter Braak, C. J. F. (1986). Canonical correspondence analysis: a new eigenvector technique for multivariate direct gradient analysis. Ecology, 67, 1167-1179.

Torres-Alvarado, M. R., Fernández, F. J., Ramírez-Vives, F., \& Varona-Cordero, F. (2013). Dynamics of the methanogenic archaea in tropical estuarine sediments. Archaea, Special Issue "Archaea in Past and Present Geobiochemical Processes and Elemental Cycles", 1-13. 
Visser, A., Beeksman, I., van der Zee, F., Stams, A. J M., \& Lettinga, G. (1993). Anaerobic degradation of volatile fatty acids at different sulphate concentrations. Applied Microbiology and Biotechnology, 40, 549-556.

Widdel, F., \& Hansen, T. A. (1992). The dissimilatory sulfate- and sulfur-reducing bacteria. In A. Balows, $\mathrm{H}$. G. Trüper, M. Dworkin, W. Harder \& K. H. Schleifer (Eds.), The Prokaryotes I (pp. 583-616). New York: Springer-Verlag.
Wilms, R., Sass, H., Köpke, B., Cypionka, H., \& Engelen, B. (2007). Methane and sulfate profiles within the subsurface of a tidal flat are reflected by distribution of sulfate-reducing bacteria and methanogenic archaea. FEMS Microbial Ecology, 59, 611-621.

Zepp-Falz, K., Holliger, C., Grosskopf, R., Liesack, W., Nozhevnikova, A. N., Müller, B., ... Hahn, D. (1999). Vertical distribution of methanogen in the anoxic sediment of Rotse (Swizerland). Applied and Environmental Microbiology, 65, 2402-2408. 